\title{
RELATIONSHIP BETWEEN ADIPOKINES, INFLAMMATION, AND VASCULAR REACTIVITY IN LEAN CONTROLS AND OBESE SUBJECTS WITH METABOLIC SYNDROME
}

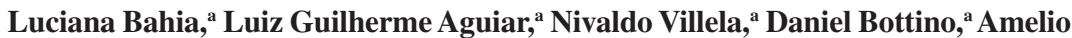

F. Godoy-Matos, ${ }^{\mathrm{b}}$ Bruno Geloneze, ${ }^{\mathrm{c}}$ Marcos Tambascia, ${ }^{\mathrm{c}}$ and Eliete Bouskela ${ }^{\mathrm{a}}$

Bahia L, Aguiar LG, Villela N, Bottino D, Godoy-Matos AF, Geloneze B et al. Relationship between adipokines, inflammation, and vascular reactivity in lean controls and obese subjects with metabolic syndrome. CLINICS. 2006;61(5):433-40.

PURPOSE: Metabolic syndrome is an important risk factor for cardiovascular disease. Adipokines interfere with insulin action and endothelial cell function. We investigated the relationship among adipokines, metabolic factors, inflammatory markers, and vascular reactivity in obese subjects with metabolic syndrome and lean controls.

METHODS: Cross-sectional study of 19 obese subjects with metabolic syndrome and 8 lean volunteers evaluated as controls. Vascular reactivity was assessed by venous occlusion pletysmography measuring braquial forearm blood flow (FBF) and vascular resistance (VR) responses to intra-arterial infusions of endothelium-dependent (acetylcholine-Ach) and independent (sodium nitroprusside-SNP) vasodilators. Blood samples were obtained to evaluate $\mathrm{C}$ reactive protein (CRP), plasminogen activator inhibitor 1 (PAI-1), fibrinogen, adiponectin, resistin, and lipid profile. Patients were classified with regard to insulin resistance through the HOMA-IR index.

RESULTS: PAI-1, CRP and fibrinogen were higher and adiponectin was lower in metabolic syndrome subjects compared to controls. Metabolic syndrome subjects had impaired vascular reactivity. Adiponectin and PAI-1 were associated with insulin, HOMA-IR, triglycerides, and HDLc; and resistin with CRP. Adiponectin was associated with VR after Ach in the pooled group and resistin with D FBF after Ach in the metabolic syndrome group.

CONCLUSION: Metabolic syndrome subjects exhibited low levels of adiponectin and high levels of CRP, fibrinogen, and PAI1. Adiponectin and PAI-1 correlated with insulin resistance markers. Adiponectin and resistin correlated with vascular reactivity parameters. An adipocyte-endothelium interaction might be an important mechanism of inflammation and vascular dysfunction.

KEYWORDS: metabolic syndrome. Adipokines. Vascular reactivity. Inflammation markers. Venous occlusion plethysmography.

\section{INTRODUCTION}

Metabolic syndrome (MetSyn) comprises an array of cardiovascular risk factors such as abdominal obesity,

aDepartment of Physiological Sciences - Institute of Biology Roberto Alcântara Gomes, State University of Rio de Janeiro - Rio de Janeiro, Brazil.

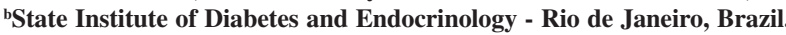
'Endocrinology Department, Universidade Estadual de Campinas (UNICAMP) - São Paulo, Brazil.

Email: eliete_bouskela@yahoo.com.br

Received for publication on April 19, 2006.

Accepted for publication on July 18, 2006. dyslipidemia, hypertension, and impaired glucose tolerance. Insulin resistance (IR) and/or increased abdominal (visceral) obesity have been suggested as potential ethiological factors. Insulin resistance has negative effects on arterial and arteriolar function throughout the body. ${ }^{1}$ In addition to the link between IR and the development of type 2 diabetes, IR-associated dysfunction of resistance vessels is related to arterial hypertension and vascular occlusive diseases, such as myocardial infarction and stroke., ${ }^{2,3}$ The underlying mechanism of vascular dysfunction, at the endothelium and smooth muscle levels, appears to be second- 
ary to excessive generation of reactive oxygen species (ROS), a process denominated oxidative stress. Other factors, such as increased production of vasoconstrictive agents, also seem to restrict the dilator responses. The underlying cause of augmented ROS availability is not completely understood, but vascular inflammatory processes appear to be involved. Increasing evidence has associated insulin resistance with subclinical inflammation involving cytokines derived from adipose tissue. ${ }^{4}$ Metabolic syndrome has also features of a pro-thrombotic state, consisting of increased levels of 3 clotting factors (tissue factor, factor VII, and fibrinogen) as well as inhibition of the fibrinolytic pathway with increased plasminogen activator inhibitor 1 (PAI-1) and decreased tissue plasminogen activator activity. ${ }^{5}$

Adipose tissue is not an inert storage depot, but rather a tissue actively secreting a variety of bioactive substances, known as adipokines, with autocrine, paracrine, and endocrine actions that probably contribute to the increased risk of type 2 diabetes and cardiovascular disease. Adiponectin, a newly found adipose tissue-specific collagen-like protein, has been noted as an important antiatherogenic and antiinflammatory protein. ${ }^{6,7}$ On the other hand, resistin, also produced by the adipose tissue, has been identified in several others tissues. ${ }^{8}$ More recently, it has been found in monocytes and is suggested to be intrinsically related to the inflammatory process. ${ }^{9}$ Resistin antagonizes insulin action and has been shown to impair glucose metabolism in wild-type mice. Increased levels of resistin mRNA have been detected in genetic and diet-induced obesity models, ${ }^{10}$ although in humans there is uncertainty about the relationships between resistin, body fat mass, and insulin resistance markers. ${ }^{11}$ PAI-1, also secreted by adipocytes, is associated with increased cardiovascular events in diabetic, obese, and insulin-resistant subjects. ${ }^{12-14}$

To elucidate the relationship among adipokines, inflammation, IR, and endothelial function, we performed a crosssectional study comparing obese subjects with metabolic syndrome to lean controls.

\section{SUBJECTS AND METHODS}

The present study, approved by the local Ethical Committee, included 19 nonsmoking subjects with MetSyn and 8 healthy volunteers. The general characteristics of both groups are described in Table 1. All subjects were selected at the Cardiometabolic Clinic for outpatient care at the State University of Rio de Janeiro. All of them signed an informed consent form approved by the Ehics Committee. At the first clinical visit, they were subjected to a complete clinical examination, went through a 10 to $12 \mathrm{~h}$ fast-
Table 1 - General characteristics of control and metabolic syndrome (MetSyn) groups

\begin{tabular}{lccc}
\hline & $\begin{array}{c}\text { MetSyn } \\
\mathrm{n}=19\end{array}$ & $\begin{array}{c}\text { Control } \\
\mathrm{n}=8\end{array}$ & $P$ value \\
\hline $\begin{array}{l}\text { Age (years) } \\
\text { Gender (male/female) }\end{array}$ & $40.8 \pm 9.4$ & $25.7 \pm 3.9$ & $<0.001$ \\
$\begin{array}{l}\text { Weight }(\mathrm{kg}) \\
\text { BMI }\left(\mathrm{kg} / \mathrm{m}^{2}\right)\end{array}$ & $102.5 \pm 16$ & $62.4 \pm 12.8$ & $<0.001$ \\
$\begin{array}{l}\text { Waist circumference }(\mathrm{cm}) \\
\quad \text { women } \\
\quad \text { men }\end{array}$ & $106.5 \pm 9.6$ & $64.5 \pm 5.2$ & $<0.001$ \\
$\begin{array}{l}\text { Waist-hip ratio } \\
\quad \text { women }\end{array}$ & $0.90 \pm 0.006$ & $0.71 \pm 0.004$ & $<0.001$ \\
$\quad 0.97 \pm 0.007$ & $0.86 \pm 0.004$ & $<0.001$ \\
$\begin{array}{l}\text { Systolic blood pressure } \\
\text { (mm Hg) }\end{array}$ & $150.0 \pm 16.6$ & $115.1 \pm 11.4$ & $<0.001$ \\
$\begin{array}{l}\text { Diastolic blood pressure } \\
\text { (mm Hg) }\end{array}$ & $86.9 \pm 9.6$ & $71.0 \pm 10.7$ & 0.001 \\
\hline
\end{tabular}

MetSyn: metabolic syndrome group; BMI: body mass index; ns=not significant

ing lipid profile and a 75-g oral glucose tolerance test. All subjects were found positive for at least 3 criteria for MetSyn according to NCEP-ATPIII. ${ }^{15}$ The same trained examiner collected anthropometric measurements twice: waist circumference at its smallest point with the abdomen relaxed, hip circumference at the widest part at the gluteal region and weight using a digital scale (Filizola, Rio de Janeiro, RJ-Brazil). Blood pressure (BP) was also measured twice after a five-minute rest in the supine position using an automated apparatus (Multiparameter patient monitor - Lifewindow LW6000, Digicare Biomedical Technology, West Palm Beach, WA-USA). Subjects with hypertension were instructed not to stop taking their anti-hypertensive medication. None was using angiotensin-converting enzyme blockers, angiotensin II antagonists or cholesterol lowering drugs. Subjects were excluded for any of the following reasons: diabetes mellitus type 2, smoking habit, coronary heart disease or any major active medical issues.

\section{VASCULAR REACTIVITY TESTS}

We performed venous occlusion plethysmography after intra-arterial infusions of endothelium-dependent (Ach) and independent (SNP) vasodilators, an accurate technique to study vascular reactivity in humans, which indirectly assess endothelial function. Forearm blood flow (FBF) and vascular resistance (VR) responses to intra-arterial infusions of Ach and SNP were analyzed. This study was performed in the morning period after a 8 to 10-hour overnight fast and in a temperature controlled room $\left(20-22^{\circ} \mathrm{C}\right)$. A $27-$ gauge spinal needle (Becton, Dickinson Ind Cirurgicas Ltda, Juiz de Fora, MG-Brazil) was inserted into the left 
brachial artery, anterior to the elbow, under sterile conditions and local anesthesia. Baseline measurements of FBF, $\mathrm{BP}$ and heart rate were obtained after catheter insertion followed by a 20-minute rest. A mercury-filled silastic straingauge was placed on the upper third of the forearm in the point of maximal circumference. The arm collecting cuff pressure was $40 \mathrm{~mm} \mathrm{Hg}$ and the wrist cuff occlusion pressure was $200 \mathrm{~mm} \mathrm{Hg}$. Wrist cuff was inflated 1 minute before each flow measurement to avoid hand shunt. By blocking venous efflux with the upper arm cuff, the slope of change in forearm volume expresses FBF. Blood pressure was measured noninvasively simultaneously in the right arm at each period. Baseline blood flow was recorded after a 20-minute infusion of saline at a rate of $0.8 \mathrm{~mL} /$ minute delivered by a Harvard pump (Harvard Apparatus Inc, South Natick, Massachusetts-USA). Ach and SNP were infused for 5 minutes each at progressive doses: 7.5, 15, and 30 $\mathrm{mg} / \mathrm{minute}$ and 2, 4, and $8 \mathrm{mg} / \mathrm{minute}$, respectively. Blood flow was measured during the last 2 minutes for each dose and was recorded for $10 \mathrm{~s}$ in every $15 \mathrm{~s}$. There was a 20minute interval between each drug infusion. Forearm vascular resistance (VR), expressed in arbitrary units, was calculated by dividing mean BP by FBF for each recorded period. The plethysmograph (Hokanson EC6, D.E. Honkanson Inc, Bellevue, WA, USA) was connected to an analog-to-digital converter (8SP, AD Instruments Pty Ltd, Castle Hill-Australia) and the data was analyzed by Power Lab software on an IBM PC compatible.

\section{LABORATORY ANALYSIS}

Fasting plasma glucose, total cholesterol, triglycerides, and HDL-cholesterol (HDLc) were measured by enzymecolorimetric GOD-PAP automated method (Modular Analytics PP, Roche). LDL cholesterol was calculated by the Friedwald equation. Fasting plasma insulin, C-reactive protein (CRP), and fibrinogen were measured by automated chemoluminiscence (coefficient of variation-CV $4.68 \%$ ), immunoturbimetric (CV 2.14\%), and coagulometric (CV $1.6 \%$ ) methods, respectively. Blood samples were centrifuged and stored at $-70^{\circ} \mathrm{C}$ for further analysis of adipokines. Adiponectin (Adp), resistin, and PAI-1 were measured by human serum adipokine (panel A, Lincoplex kit CATHADK1-61K-A, Linco Research-St Charles, Missouri USA). The intra and inter-assay CV were $6.11 \%$ and $13.2 \%$, $7.26 \%$ and $9.12 \%$, and $4.37 \%$ and $20.8 \%$, respectively. HOMA-IR was calculated to assess insulin resistance. ${ }^{16}$

\section{STATISTICAL ANALYSIS}

Data were analyzed using SPSS 10.0 software for Win- dows (SPSS, Chicago, IL-USA). Comparisons between groups were performed by independent samples Student $t$ test and Mann Whitney tests, as indicated. Correlation analysis was performed by Spearman rank order test. All group data are reported as mean $\pm \mathrm{SD}$, except for non-normal variables. Logarithmic transformation was used to normalize non-normally distributed variables. Significant differences were assumed when $P<0.05$.

\section{RESULTS}

The differences in laboratory parameters are displayed in Table 2. As expected, MetSyn group had higher fasting plasma glucose, insulin and HOMA-IR. Adiponectin was lower, whereas PAI-1, CRP and fibrinogen were higher in the MetSyn group compared to the control group. Resistin values were not different between groups.

Table 2 - Laboratory measurements in control and metabolic syndrome (MetSyn) groups

\begin{tabular}{lccc}
\hline & $\begin{array}{c}\text { MetSyn } \\
\mathrm{n}=19\end{array}$ & $\begin{array}{c}\text { Control } \\
\mathrm{n}=8\end{array}$ & $P$ value \\
\hline Glucose $(\mathrm{mmol} / \mathrm{l})$ & $5.43 \pm 0.73$ & $4.71 \pm 0.47$ & $\mathbf{0 . 0 1}$ \\
2h post-load glucose & $7.7 \pm 1.94$ & $5.73 \pm 0.55$ & $\mathbf{0 . 0 0 1}$ \\
(mmol/l) & & & \\
Insulin (mUI/ml) & $14.4 \pm 4.6$ & $4.1 \pm 1.7$ & $<\mathbf{0 . 0 0 1}$ \\
HOMA-IR & $3.4 \pm 1.2$ & $1.0 \pm 0.4$ & $<\mathbf{0 . 0 0 1}$ \\
Total Cholesterol (mmol/l) & $5.12 \pm 0.86$ & $4.71 \pm 1.7$ & 0.26 \\
LDLc (mmol/l) & $3.29 \pm 0.81$ & $2.79 \pm 0.56$ & 0.12 \\
HDLc (mmol/l) & & & \\
\multicolumn{1}{c}{ women } & $1.13 \pm 0.37$ & $1.85 \pm 0.31$ & $\mathbf{0 . 0 0 1}$ \\
$\quad$ men & $1.10 \pm 0.18$ & $1.44 \pm 0.15$ & $\mathbf{0 . 0 0 1}$ \\
Triglycerides (mmol/l) & $1.81 \pm 0.81$ & $0.61 \pm 0.25$ & $<\mathbf{0 . 0 0 1}$ \\
CRP (mg/dl) & $1.0[0.5-2.0]$ & $0.3[0.2-0.45]$ & $\mathbf{0 . 0 0 2}$ \\
Fibrinogen (mmol/l) & $3.04 \pm 0.76$ & $2.40 \pm 0.34$ & $\mathbf{0 . 0 4}$ \\
Adiponectin (mg/ml) & $9.5[3.7-14.2]$ & $19.5[8.6-53.4]$ & $\mathbf{0 . 0 3}$ \\
Resistin (ng/ml) & $18.9 \pm 4.8$ & $17.2 \pm 2.2$ & 0.36 \\
PAI-1 (ng/ml) & $25.9 \pm 6.6$ & $14.3 \pm 4.3$ & $<\mathbf{0 . 0 0 1}$ \\
\hline
\end{tabular}

MetSyn: metabolic syndrome group; CRP: ultra sensitive C-reactive protein; PAI-1: plasminogen activator inhibitor-1. * Data are expressed by mean \pm $\mathrm{SD}$ or median [IQR]

In the pooled group, adiponectin was associated with insulin ( $\mathrm{r}=-0.50, P=0.009)$, HOMA-IR ( $\mathrm{r}=-0.41, P=$ $0.04)$, triglycerides $(\mathrm{r}=-0.44, P=0.02)$, and HDLc $(\mathrm{r}=$ $0.49, P=0.01)$. PAI- 1 was associated with glucose $(\mathrm{r}=$ 0.67, $P<0.001)$, insulin ( $\mathrm{r}=0.68, P<0.001)$, HOMA-IR ( $\mathrm{r}=0.69, P<0.001)$, triglycerides $(\mathrm{r}=0.53, P=0.02)$, CRP (r = 0.39, $P=0.004)$, and HDLc $(\mathrm{r}=-0.55, P=0.003)$ in the pooled group. In the MetSyn group, PAI-1 was associated with glucose $(\mathrm{r}=0.53, P=0.01)$ and HOMA-IR ( $\mathrm{r}=0.50, P=0.02)$. Resistin was associated with CRP ( $\mathrm{r}=$ $0.42, P=0.02$ ) only in the MetSyn group.

The MetSyn group had impaired endothelium-dependent and independent vasodilation compared to the control 
group (Figures 1 and 2). No association could be found between PAI-1 and vascular reactivity measurements in both groups. Adiponectin was associated with DVR after Ach ( $\mathrm{r}=0.39, P=0.05)$ in the whole group, although after adjustments to metabolic parameters, this relationship was not significant any more. In the MetSyn group, resistin was associated with D FBF after Ach $(\mathrm{r}=-0.47, P=0.04)$, but again, after adjustment to CRP, this relationship disappeared (Figures 3 and 4).

\section{DISCUSSION}

In a previous study ${ }^{17}$ we have shown that endothelial dysfunction correlates with markers of obesity. In this study, we show that subjects with MetSyn exhibited impaired endothelium-dependent and independent vasodilation responses compared to the control group, as has already been shown in other studies in obese and type 2 diabetic sub-
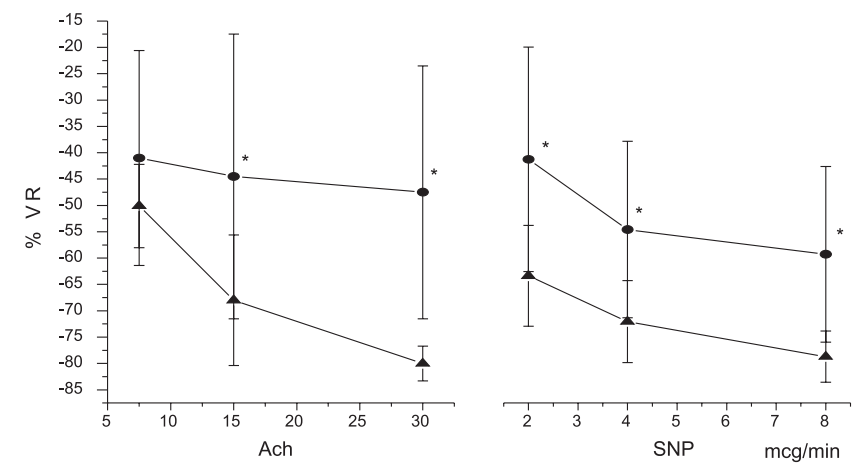

Figure 1 - Vascular resistance decrement (\%) after Ach and SNP infusion in subjects with MS (.) and controls (2\%). ( ${ }^{*} P<0.05$ intergroup)

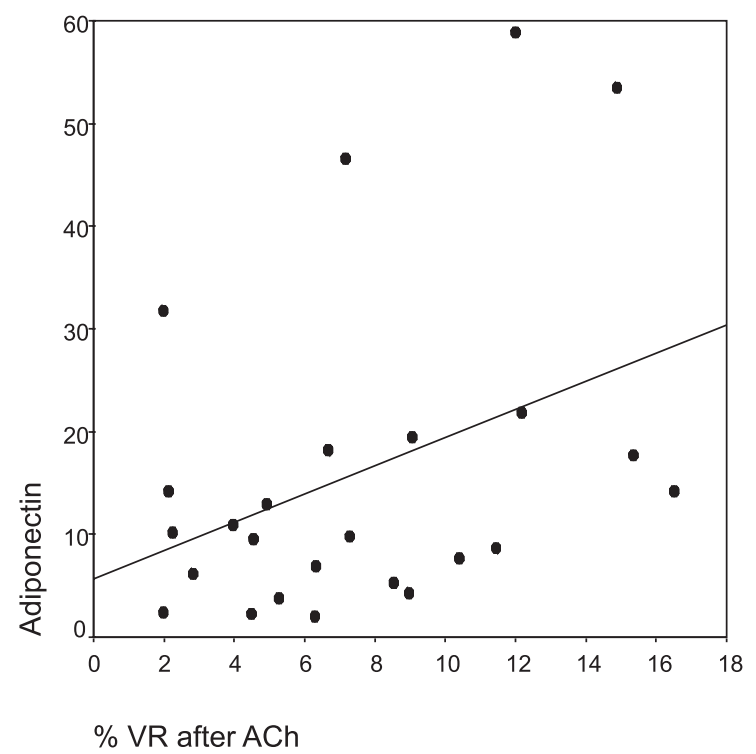

Figure 3 - Relationship between vascular resistance decrement (\%) after Ach and adiponectin level in the pooled group jects, ${ }^{18,19}$ and is considered a risk factor for future cardiovascular ischemic events. ${ }^{20}$ There is increasing evidence that new cases of cardiovascular diseases are closely associated with increased prevalence of insulin resistance and type 2 diabetes due to excessive weight and sedentary lifestyle..$^{21,22}$ The convergence between insulin resistance and inflammation in the pathogenesis of atherosclerotic coronary disease has been recognized over the past decade, ${ }^{4,23}$ but the exact mechanism by which excessive adiposity causes both insulin resistance and vascular dysfunction is not completely understood. Much of the recent work on obesity has highlighted the key role of adipose tissue as an endocrine organ secreting a large number of substances that mediate vascular and metabolic complications of obesity.

Resistin, as suggested by its name, should be related to insulin resistance, but a lot of controversy surrounds its exact biological role in humans. Even without significant differences between the two groups studied, we were able

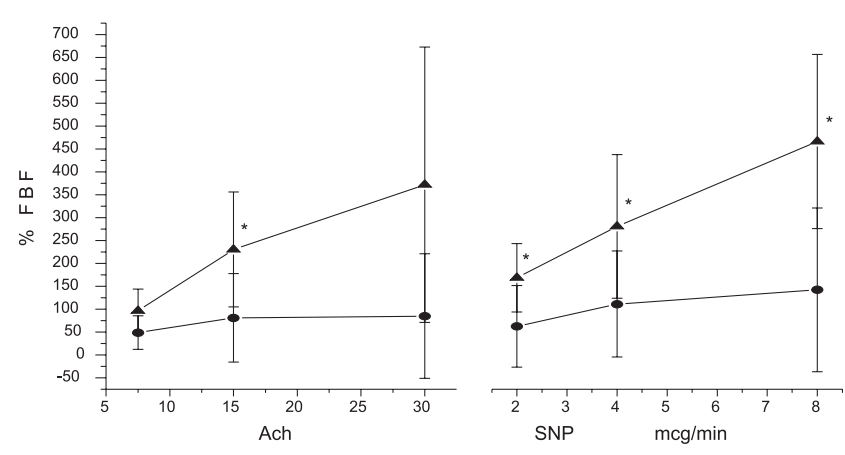

Figure 2 - Forearm blood flow increment (\%) after Ach and SNP infusion in subjects with $\mathrm{MS}(\cdot)$ and controls $(2 \%) .(* P<0.05$ intergroup)

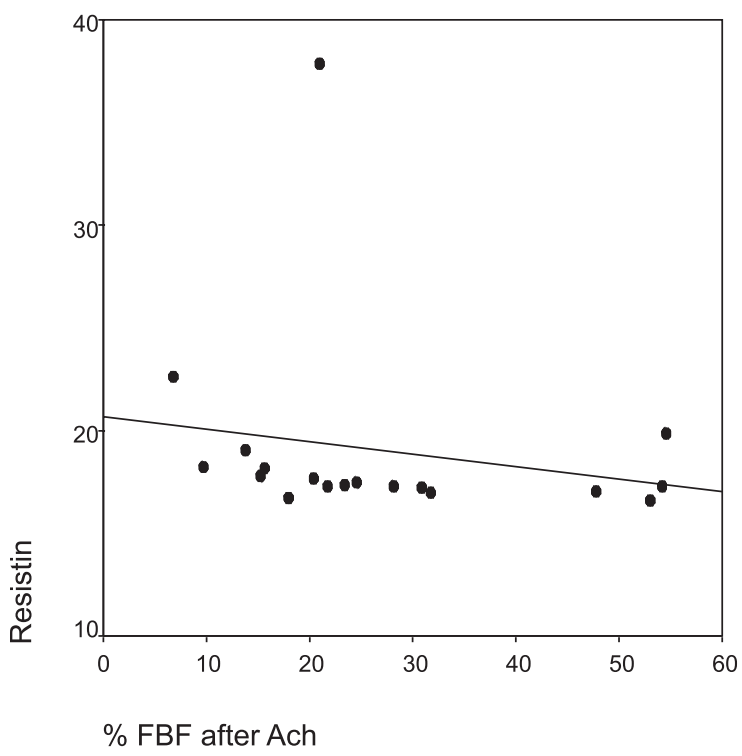

Figure 4 - Relationship between forearm blood flow increment (\%) and resistin level in the pooled group 
to show an inverse relationship between resistin and endothelium-dependent vasodilation in the MetSyn group. To our knowledge, this is the first study demonstrating this relationship in humans. Verma and co-workers ${ }^{24}$ reported, for the first time, that human recombinant resistin exerted direct effects on cultured endothelial cells, promoting endotelin-1 release and upregulating adhesion molecules and cytokines, possibly a link between this adipokine and vascular dysfunction. Other authors have shown that resistin can cause endothelial dysfunction in porcine coronary arteries through oxidative stress and down-regulation of endothelial nitric oxide synthase ${ }^{25}$ and that it can induce human aortic smooth muscle cells proliferation. ${ }^{26}$

We could not demonstrate a difference in resistin levels between the two groups and any relationship between resistin and IR markers. The analysis of several published studies show conflicting results, some demonstrating a close relationship between resistin and insulin resistance ${ }^{27}$ while many others arrive at the opposite conclusion. ${ }^{28-30}$ The positive correlation between resistin and CRP found in this study and also in others, ${ }^{31-33}$ suggests a direct proinflammatory role of resistin that might be involved in the inflammatory vascular process. ${ }^{34}$ In contrast to what was found in rodents, human resistin is expressed primarily in inflammatory cells, ${ }^{9}$ and its expression is markedly increased by treatment with endotoxin and proinflammatory cytokines in vitro. ${ }^{35}$ At cellular level, resistin has been shown to exert pro-inflammatory properties by up-regulating cytokines, probably via the NFk-B payhway. ${ }^{36}$ We found that resistin was associated with CRP and endothelial-dependent vasodilation only in MetSyn group, with higher CRP and lower vasodilation capacity. When adjustment for CRP was done, the relationship between resistin and endothelial-mediated vasodilation disappeared. Considering the expression of resistin by mononuclear cells and assuming that obesity and MetSyn are states of low-grade inflammation, resistin may indeed represent a molecular link between metabolic signals, inflammation, and vascular dysfunction. Remarkably, Reilly and co-workers ${ }^{31}$ showed, in a large study of 879 humans at high risk for coronary atherosclerosis, the relationship between resistin and diverse inflammatory markers, as well as with coronary atherosclerosis.

A positive association between PAI-1 and insulin resistance markers has been shown by several studies in insulin-resistant, obese and nonobese subjects. ${ }^{12-14}$ We also demonstrated correlations between PAI-1, insulin resistance, and inflammatory markers. Chronic inflammation of the vascular wall shifts haemostatic mechanisms in favor of thrombosis. The possible mechanisms involved are enhanced clotting process, impaired fibrinolysis capacity and decreased natural anticoagulant pathways. ${ }^{35-38} \mathrm{C}$-reactive protein and other inflammatory mediators can down-regulate the protein $\mathrm{C}$ and thrombomodulin receptors of endothelial cells. In response there is an increase in cytokine expression and endothelial cell injury, creating a vicious cycle. ${ }^{37}$ Therefore, factors of haemostatic and fibrinolytic systems could be directly linked to insulin-resistance syndrome or be a reflection of endothelial cell activation and chronic low-grade inflammation.

Plasma levels of adiponectin were reduced in MetSyn group compared to the control group, which is in accordance to various studies showing reduced adiponectin levels in obese, diabetic, coronary heart disease, and hypertensive subjects. ${ }^{39-41}$ There was an inverse correlation between adiponectin and insulin-resistance markers in the whole group. The exact mechanism underlying the observed association between adiponectin and insulin is presently unknown. In rhesus monkeys, the hyperinsulinemiceuglycemic clamp revealed a positive correlation between adiponectin and glucose uptake and, longitudinally, plasma adiponectin decreased in parallel to the progression of insulin resistance. ${ }^{42}$ In in vitro and animal studies, insulin enhances adiponectin secretion, ${ }^{43,44}$ suggesting that adiponectin secretion might be disturbed in the insulin-resistance states. Indeed, the administration of recombinant adiponectin in lipoatrophic mice caused a reversal of insulin resistance. ${ }^{45}$

In this cross-sectional study, we only found a tendency for correlation between adiponectin and endothelial dependent-vasodilation in the whole group, although this association disappeared after adjusting to metabolic parameters. There are several studies showing that adiponectin favorably affects endothelial function and vascular homeostasis. ${ }^{45-47}$ Although there is evidence of direct effects of adiponectin on endothelial cells, the lack of correlation after adjustments to metabolic parameters in our sample does not confirm it. In human studies, the relationship between adiponectin and endothelial function has been demonstrated in obese, type 2 diabetic, hypertensive subjects and in healthy subjects. ${ }^{48-51}$ We found that adiponectin was indeed decreased in subjects with MetSyn who also demonstrated an impaired endothelial-dependent vasodilation. The absence of correlation with vascular reactivity in MetSyn group could eventually be explained by our small sample size. Adiponectin might have a protective role in vascular function and high levels of adiponectin correlates to less coronary heart events in men with and without diabetes. ${ }^{52,53}$ Further larger studies are needed to address whether interventions that increase adiponectin levels can improve endothelial function and reduce cardiovascular events. 
This is the first study showing a relationship between resistin and vascular reactivity in MetSyn subjects, although it has some limitations due its small sample, but also because the comparison of groups was not matched by age, and because it was not possible to separate subgroups.

In conclusion, adiponectin and PAI-1 correlated with insulin-resistance markers, but resistin did not. In contrast with the initial studies connecting resistin to IR, our results are in line with others suggesting a proinflammatory role of resistin interfering with vascular function. An adipocyte-endothelium interaction may be an important mechanism of inflammation and vascular dysfunction leading to increased cardiovascular disease in obesity. However, the exact mechanism linking resistin and adiponectin to the pathogenesis of obesity-induced insulin resistance and cardiovascular disease deserves further studies.

\section{ACKNOWLEDGEMENTS}

The work was supported by a grant from the national research Council of Brazil (CNPq number 505860/2004-0).

The authors wish to thank Mr Francisco Araujo, Mrs Cristiane Conte, Mrs Camila Laflor, Mrs Sofia Gama and Dr Beatriz Schaan for their technical help.

Part of this work has been presented as an abstract in Arq Bras Endocrinol Metab 2005;49(5):S878.

\section{RESUMO}

Bahia L, Aguiar LG, Villela N, Bottino D, Godoy-Matos AF, Geloneze B et al. Relação entre as adipocinas, inflamação e reatividade vascular em controles magros e pacientes obesos com síndrome metabólica. CLINICS. 2006;61(5):433-40.

A Síndrome Metabólica é um importante fator de risco para doenças cardiovasculares. As adipocinas interferem com a ação da insulina e com a função endotelial.

OBJETIVO: Investigar a relação entre adipocinas, fatores metabólicos, marcadores inflamatórios e reatividade vascular para inferência da função endotelial em pacientes obesos e controles magros.

MATERIAL E MÉTODO: Estudo transversal de 19 pacientes obesos com Síndrome Metabólica e 8 controles magros. A reatividade vascular foi avaliada pela pletismografia de oclusão venosa medindo o fluxo sangüíneo da artéria braquial e sua resistência vascular a partir de infusões intra-arteriais de vasodilatadores endotélio-dependente (acetilcolina) e endotélio-independente (nitroprussiato de sódio). Foram também avaliados no sangue a proteína $\mathrm{C}$ reativa (PCR), o inibidor do ativador do plasminogênio 1 (PAI-1), fibrinogênio, adiponectina, resistina e o perfil lipídico. Os pacientes foram classificados quanto à resistência insulínica pelo índice HOMA-IR.

RESULTADO: PAI-1, PCR e fibrinogênio apresentaram valores mais altos e a adiponectina mais baixos para os pacientes com Síndrome Metabólica do que com os controles. Pacientes com Síndrome Metabólica apresentaram prejuízo da reatividade vascular. A adiponectina e PAI-1 estiveram associadas à insulina, HOMA-IR, triglicerídeos e HDLc; e resistina com o PCR. Adiponectina esteve associada com a resistência vascular e a resistina com o fluxo sangüíneo depois da acetilcolina em pacientes com Síndrome Metabólica.

CONCLUSÃO: Pacientes com Síndrome Metabólica exibiram baixas concentrações sangüíneas de adiponectina e altos níveis de PCR, fibrinogênio e PAI-1. Adiponectina e PAI-1 correlacionaram com os marcadores da resistência insulínica. Adiponectina e resistina correlacionaram com a reatividade vascular. A interação adipócito-endotélio vascular pode ser um importante mecanismo de inflamação e disfunção vascular.

UNITERMOS: Síndrome Metabólica. Adipocinas. Reatividade vascular. Marcadores inflamatórios. Pletismografia de oclusão venosa.

\section{REFERENCES}

1. Arcaro G, Cretti A, Balzano S, Lechi A, Muggeo M, Bonora E, et al. Insulin causes endothelial dysfunction in humans: sites and mechanisms. Circulation. 2002;105:576-82.

2. Lakka HM, Laaksonen DE, Lakka TA, Niskanen LK, Kumpusalo E, Tuomilehto J, et al. The metabolic syndrome and total and cardiovascular disease mortality in middle-aged men. JAMA. 2002;288:2709-16.
3. Isomaa B, Almgren P, Tuomi T, Forsen B, Lahti K, Nissen M, et al. Cardiovascular morbidity and mortality associated with the metabolic syndrome. Diabetes Care. 2001, 24:683-9.

4. Andreas F, D’Agostino R, Howard G, Mykkanen L, Russel T, Haffner S. Chronic subclinical inflammation as part of the insulin resistance syndrome: the insulin resistance atherosclerosis study (IRAS). Circulation. 2000;102:42-7. 
5. De Pergola G, Pannacciulli N. Coagulation and fibrinolysis abnormalities in obesity. J Endocrinol Invest. 2002;25:899-904.

6. Maeda K, Okubo K, Shimomura I, Funahashi T, Matsuzawa Y, Matsubara K. cDNA cloning and expression of a novel adipose specific collagen-like factor, apM1 (AdiPose Most abundant Gene transcript 1). Biochem Biophys Res Commun. 1996;221:286-9.

7. Funahashi T, Nakamura T, Shimomura I, Maeda K, Kuriyama H, Takahashi M, et al Role of adipocytokines on the pathogenesis of atherosclerosis in visceral obesity. Intern Med. 1999;38:202-6.

8. Adeghate E. An update on the biology and physiology of resistin. Cell Mol Life Sci. 2004;61:2485-96.

9. Yang RZ, Huang Q, Xu A, McLenithan JC, Eisen JA, Shuldiner AR, et al. Comparative studies of resistin expression and phylogenomics in humans and mouse. Biochem Biophys Res Commun. 2003;310:927-35.

10. Steppan CM, Bailey ST, Bhat S, Brown EJ, Banerjee RR, Wright CM. The hormone resistin links obesity to diabetes. Nature. 2001;409:307312

11. Rea R, Donnelly R. Resistin: an adipocyte-derived hormone. Has it a role in diabetes and obesity? Diabetes, Obesity and Metab. 2004;6:163170

12. Meade TW, Ruddock V, Stirling Y, Chakrabarti R, Miller GJ. Fibrinolytic activity, clotting factors and long-term incidence of ischaemic disease in the Northwick Park Heart Study. Lancet. 1993;342:1076-9.

13. Ridker PM, Hennekens CH, Stampfer MJ, Manson JE, Vaughan DE. Prospective study of endogenous tissue plasminogen activator and risk of stroke. Lancet. 1994;343:940-3.

14. Vague J, Alessi MC. PAI-1, obesity, insulin resistance and risk of cardiovascular events. Thromb Haemost. 1997;78:656-60.

15. Third Report of the National Cholesterol Education Program (NCEP) Expert Panel on Detection, Evaluation, and Treatment of High Blood Cholesterol in Adults (Adult Treatment Panel III) final report. Circulation. 2002;106:3143-421.

16. Matthews DR, Hosker JP, Rudenski AS, Naylor BA, Teacher DF, Turne RC. Homeostasis model assessment: insulin resistance and beta cell function from fasting plasma glucose and insulin concentration in man. Diabetologia. 1985;28:412-9.

17. Villela NR, Aguiar LGK, Bahia L, Bottino D, Bouskela E. Does endothelial dysfunction correlate better with waist-to-hip ratio than with body mass index or waist circumference among obese patients? Clinics. 2006;61:53-57.

18. Steinberg HO, Chaker H, Leaming R, Johnson A, Bretchel D, Baron AD. Obesity/insulin resistance is associated with endothelial dysfunction. J Clin Invest. 1996;97:2601-10.

19. McVeigh GE, Brennan GM, Johnston GD, McDermott BJ, McGrath LT, Henry WR, et al. Impaired endothelium-dependent and independent vasodilation in patients with type 2 diabetes mellitus. Diabetologia. 1992;35:771-6

20. Quyyumi AA. Prognostic value of endothelial function. Am J Cardiol 2003;91(12A):19H-24H.

21. McNeill AM, Rosamond WD, Girman CJ, Golden SH, Schmidt MI, East HE, et al. The metabolic syndrome and 11-year risk of incident cardiovascular disease in the atherosclerosis risk in communities study. Diabetes Care 2005;28(2):385-90.
22. Kannel WB, McGee DL. Diabetes and cardiovascular disease. The Framingham study. JAMA. 1979;241:2035-8.

23. Ross R. Atherosclerosis: an inflammatory disease. N Eng J Med. 1999;340:115-26

24. Verma S, Li SH, Wang CH, Fedak PW, Li RK, Weisel RD, et al. Resistin promotes endothelial cell activation. Circulation. 2003;108:736-40.

25. Kougias P, Chai H, Lin PH, Lumsden AB, Yao Q, Chen C. Adipocytederived cytokine causes endothelial dysfunction of porcine coronary arteries. J Vas Surg. 2005;41:691-8

26. Calabro P, Samudio I, Willerson JT, Yeh ET. Resistin promotes smooth muscle cell proliferation through activation of extracelular signalregulated kinase and phosphatidylinositol 3-kinase. Circulation. 2004;10:3335-40

27. Silha JV, Krsek M, Skrha JV, Sucharda P, Nyomba BL, Murphy LJ. Plasma resistin, adiponectin and leptin levels in lean and obese subjects: correlations with insulin resistance. Eur J Endocrinol. 2003;149:331-5.

28. Junke J, Engeli S, Corselniak K, Luft FC, Sharma AM. Resistin gene expression in human adipocytes is not related to insulin resistance. Obes Res. 2002;10:1-5

29. Azuma K, Katsukawa F, Oguchi S, Murata M, Yamazaki H, Shimada A, et al. Correlation between serum resistin level and adiposity in obese individuals. Obes Res. 2003;11:997-1001.

30. Lee JH, Chan JL, Yiannakouris N, Kontogianni M, Estrada E, Seip R, et al. Circulating resistin levels are not associated with obesity or insulin resistance in humans and are not regulated by fasting or leptin administration: cross-sectional and interventional studies in normal, insulin resistant and diabetic subjects. J Clin Endocrinol Metabo. $2003 ; 88: 4848-56$

31. Reilly AP, Lehrke M, Wolfe ML, Rohatgi A, Lazar MA, Rader AJ. Resistin is an inflammatory marker of atherosclerosis in humans. Circulation. 2005;111:932-9.

32. Shetty GK, Economides PA, Horton ES, Mantzoros CS, Veves A Circulating adiponectin and resistin levels in relation to metabolic factors, inflammatory markers, and vascular reactivity in diabetic patients and subjects at risk for diabetes. Diabetes Care. 2004;27:2450-

33. Bo S, Gambino R, Pagani A, Guidi S, Gentile L, Cassader M, et al. Relationships between human serum resistin, inflammatory markers and insulin resistance. Iny J Obes. 2005;29:1315-20.

34.Kaser S, Kaser A, Snadhofer A, Ebenbichler CF, Tilg H, Patsch JR. Resistin messenger-RNA expression is increased by proinflammatory cytokines in vitro. Biochem Biophys Res Commun. 2003;309:286-90.

35. Speidl WS, Zeiner A, Nikfardjam M, Geppert A, Jordanova N, Niessner A, et al. An increase of C-reactive protein is associated with enhanced activation of endogenous fibrinolysis at baseline but an impaired endothelial fibrinolytic response after venous occlusion. J Am Coll Cardiol. 2005;45:30-4.

36. Bokarewa M, Nagaev I, Dahlberg L, Smith U, Tarkowski A. Resistin, an adipokine with potent proinflammatory porperties. $\mathrm{J}$ immunolk. 2005;174;5789-95.

37. Esmon CT. Crosstalk between inflammation and thrombosis. Maturitas. 2004;47:305-4. 
38. Festa A, D’Agostino R Jr, Mykkanen L, Tracy RP, Zaccaro DJ, Hales $\mathrm{CN}$, et al. Relative contribution of insulin and its precursors to fibrinogen and PAI-1 in a large population with different states of glucose tolerance: the insulin resistance atherosclerosis study (IRAS). Arterioscler Thromb Vasc Biol. 1999;19:562-8.

39. Arita Y, Kihara S, Ouchi N, Takahashi M, Maeda K, Miyagawa J, et al. Paradoxical decrease of an adipose-specific protein, adiponectin, in obesity. Biochem Biophys Res Commun. 1999;257:79-83.

40. Weyer C, Funahashi T, Tanaka S, Hotta K, Matsuzawa Y, Pratley RE, et al. Hypoadiponectinemia in obesity and type 2 diabetes: close association with insulin resistance and hyperinsulinemia. J Clin Endocrinol Metab. 2001;86:1930-5.

41. Hotta K, Funahashi T, Arita Y, Takahashi M, Matsuda M, Okamoto Y, et al. Plasma concentrations of a novel, adipose-specific protein, adiponectin, in type 2 diabetic patients. Arterioscler Thromb Vasc Biol. 2000;20:1595-9.

42. Yamauchi T, Kamon J, Waki H, Terauchi Y, Kubota N, Hara K, et al. The fat-derived hormone adiponectin reverses insulin resistance associated with both lipoatrophic and obesity. Nat Med. 2001;7:941-6.

43. Hotta K, Funahashi T, Bodkin NL, Ortmeyer HK, Arita Y, Hansen BC, et al. Circulating concentrations of the adipocyte protein adiponectin are decreased in parallel with reduced insulin sensitivity during progression to type 2 diabetes in rhesus monkeys. Diabetes. 2001;50:1126-33.

44. Yamauchi T, Kamon J, Waki H, Terauchi Y, Kubota N, Hara K, et al. The fat-derived hormone adiponectin reverses insulin resistance associated with both lipoatrophy and obesity. Nat Med. 2001;7:941-6.

45. Ouchi N, Kihara S, Arita Y, Maeda K, Kuriyama H, Okamoto Y, et al. Novel modulator for endothelial adhesion molecules: adipocyte-derived plasma protein adiponectin. Circulation. 1999;100:2473-6.
46. Ouchi N, Kihara S, Arita Y, Okamoto Y, Maeda K, Kuriyama H, et al. Adiponectin, an adipocyte-derived plasma protein, inhibitis endothelial NF-kappaB signaling through a cAMP-dependent pathway. Circulation. 2000;102:1296-1301.

47. Chen H, Montagnani M, Funahashi T,Shimomura I, Quon MJ Adiponectin stimulates production of nitric oxide in vascular endothelial cells. J Biol Chem. 2003;278:45021-6.

48. Goldstein BJ, Scalia R. Adiponectin: a novel adipokine linking adipocytes and vascular function. J Clin Endocrinol Metab. 2004;89:2563-8.

49. Fernandez-Real JM, Castro A, Vazquez G, Casamitjana R, LopezBermejo A, Penarroja G, et al. Adiponectin is associated with vascular function independent if insulin sensitivity. Diabetes Care. 2004;27:73945 .

50. Shimabukuro M, Higa N, Asahi T, Oshiro Y, Takasu N, Tagawa T, et al. Hypoadiponectinemia is closely linked to endothelial dysfunction in man. J Clin Endocrinol Metab. 2003;88:3236-40.

51. Tan KC, Xu A, Chow WS, Lam MC, Ai VH, Tam SC, et al Hypoadiponectinemia is associated with impaired endotheliumdependent vasodilation. J Clin Endocrinol Metab. 2004;89:765-9.

52. Schultze MB, Rimm EB, Li T, Rifai N, Hu FB. Adiponectin and future coronary events among men with type diabetes. Diabetes. 2005;54:534-

53. Pischon T, Girman CJ, Hotamisligil GS, Rifai N, Hu FB, Rimm EB. et al. Plasma adiponectin levels and risk of myocardial infarction in men. JAMA. 2004;291:1730-7. 